\title{
Effect of Interleukin-2 on Interleukin-10 in vitro Production by Peripheral Blood Mononuclear Cells in Correlation with Hepatocyte Growth Factor Serum Levels in Patients with Chronic Renal Failure
}

\author{
Seham A. Abou Shousha, ${ }^{*}$ Hoda A-M Hamdy ${ }^{* *}$ \\ Amany I. Youssef, ${ }^{* *}$ Eman S Khalil ${ }^{* * *}$ \\ Immunology Department ${ }^{*}$, Applied Medical Chemistry Department ${ }^{* * *}$, \\ Internal Medicine Department ${ }^{* * *}$, Medical Research Institute, \\ Alexandria University
}

\begin{abstract}
Chronic Renal Failure (CRF) is associated with dysfunction of immuno-inflammatory response manifested by imbalanced production of pro- and anti-inflammatory cytokines as well as decreased $T h_{1} / T h_{2}$ ratio. In the present work, the effect of interleukin 2 (IL-2) [as the main Th cell activator] on the production of interleukin-10 (IL-10) [as a potent anti-inflammatory cytokine] by Peripheral Blood Mononuclear Cells (PBMCs) in CRF patients was studied. The study was conducted on a group of 20 patients with CRF and 10 sex and age matched normal healthy individuals as a group of control. For both groups, the levels of IL-10 were measured in IL-2supplemented and non-supplemented cell culture supernatants of PBMCs. The obtained results were correlated with serum levels of hepatocyte growth factor (HGF) as a marker of CRF associated inflammatory state. Results of the work revealed that IL-10 levels were significantly higher in both IL-2 supplemented $(P=0.000)$ and non supplemented $(P=0.000)$ PBMCs supernatants of CRF group when compared to normal one. This finding reflects the low grade systemic inflammation associated with $C R F$ that is confirmed by significantly elevated HGF serum mean level $(P=0.001)$ in CRF patients than normal subjects in the present study. These results have demonstrated that IL-2 may play a protective role in CRF patients through correction of $T h_{1} / T h_{2}$ ratio and keeping the balance between pro-and anti-inflammatory cytokines in those patients.
\end{abstract}

\section{INTRODUCTION}

Chronic renal failure (CRF) is associated with defective cellular and humeral immunity; ${ }^{(\mathbf{1})}$ this is mainly due to disturbances of $\mathrm{T}$ helper (Th) cells subsets (i.e $\mathrm{Th}_{1} / \mathrm{Th}_{2}$ ) ratio ${ }^{(2)}$ resulting in increased levels of circulating cytokines and other inflammatory markers such as proinflammatory cytokines including IL-1, IL-6, TNF ${ }^{(3)}$.

In patients with $\mathrm{CRF}$, increased serum hepatocyte growth factor (HGF) was found to be linked with the inflammatory status. It was 
reported that HGF and IL-6 up regulate each other. This could explain the increased levels of HGF in sera of CRF patients. ${ }^{(4)}$

Human HGF is synthesized as a single polypeptide chain precursor of 728 amino acid residues. It has an appreciable homology with plasminogen, and it is processed proeolytically to release an N-terminal signal peptide of 31 amino acids to generate an active heterodimer after secretion. $^{(5)}$

Hepatocyte growth factor (HGF) is emerged as multipotent growth factor that is involved in tissue regeneration, wound healing and normal tissue growth. ${ }^{(6)}$ It is a powerful stimulator of DNA synthesis in a variety of cell types, especially hepatocytes. ${ }^{(7)}$

Patients with CRF are characterized by a low-grade systemic inflammation due to uremia reflecting consequences of an imbalanced production of pro-and antiinflammatory cytokines. ${ }^{(8)}$ High level of T-lymphocyte and monocyte expression of these cytokines has been reported and reflects the chronic immune system activation. ${ }^{(9)}$

IL-2 $\left(\mathrm{Th}_{1}\right.$ cytokine) as the main activator of other Th cells and IL-10 $\left(\mathrm{Th}_{2}\right.$ cytokine) as a potent regulatory and anti-inflammatory cytokine are examples of such cytokines that might have a role in CRF pathogenesis.

Interleukin-2 (IL-2) is an autocrine and paracrine T-cell growth factor. It is a polypeptide of M.Wt 15,400 Dalton consisting of 133 amino and encoded by single gene on human chromosome $4 .{ }^{(\mathbf{1 0})}$

It plays an important role in the immune systems by inducing cell cycle progression and protection from apoptosis. ${ }^{(11)}$ Reduced cellular activity which exists in high proportion of CRF patients, could be attributed to a failure of monocyte population to support the process of primary $\mathrm{T}$ cell activation. This results in decreased production of IL-2 in those patients. ${ }^{(12,13)}$

Interleukin-10 (IL-10) is a $\mathrm{Th}_{2}$ cytokines, ${ }^{(14)}$ that is secreted by different cell population including $\mathrm{T}$ cells, monocytes, B-cells, mast cells and keratinocyte. ${ }^{(15)}$ IL-10 is an important negative regulator of cell mediated immunity and Th1 functions. However, it has a potent stimulatory effect for growth and differentiation of B lymphocytes, augmenting production of $\operatorname{IgA}, \operatorname{IgG}$ and IgE. In vitro, IL-10 supresses the synthesis of reactive oxygen species and nitric oxide and blocks cycloxygenase-2-dependent synthesis of interstitial collagenase and gelatinase $\mathrm{B}{ }^{(\mathbf{1 6})}$ It is considered to be a potent anti-inflammatory cytokine that is suggested to have a protective role against systemic inflammation by limiting the production of a broad range of pro-inflammatory factors in CRF patient. ${ }^{(3)}$

Thus, the aim of the present study was to investigate the relationship between IL-2 and IL-10 in CRF patients that could be useful in clarifying the mechanisms by which these two cytokines may participate in immunopathogenesis of the disease. To gain that aim, the plan of the work was to study the effect of IL-2 on in vitro production of IL-10 by PBMCs of CRF patients in correlation with serum level of HGF as a marker of CRF-associated inflammatory state. 


\section{SUBJECTS \& METHODS}

The study was conducted on twenty proved CRF patients (5 females and 15 males) of different causes, attending the Medical Research Institute Hospital. Their ages ranged from 36 to 69 years, with a mean of $46 \pm 2$ years. Patients were on hemodialysis for a period more than 6 months. Hemodialysis was conducted for 3-4 $\mathrm{hr} / \mathrm{session}, 2-3$ times weekly.

Careful clinical examination was performed to exclude patients with diseases that might affect the different immunological parameter. None of the patients experienced signs of diabetes mellitus, malignancy, fever or infection at the time of sampling. Blood samples were drawn from the fistula needle before the dialysis session.

Part of the blood was pipetted in EDTA-coated tube for the determination of blood $\mathrm{Hb}$, the serum was separated from the remaining blood for the determination of other parameters.

Ten normal healthy individuals ( 3 female and 7 males) with ages ranged $27-68$ years with a mean age of $45 \pm 4$ years were taken as a control group.

\section{Methods}

\section{Determination of HGF serum level}

About three $\mathrm{ml}$ of venous blood were withdrawn just before dialysis from each subject. After clotting serum samples were separated and kept at $-80^{\circ} \mathrm{C}$ till used for determination of HGF.

HGF was quantitatively measured in serum samples by ELISA Kit (RVD) system $\mathrm{GmbH}$, Germany) according to the manufactures' procedures. A monoclonal antibody specific for $\mathrm{HGF}$ was pre-coated onto a microplate (microwells). Standards (125-8000 $\mathrm{Pg} / \mathrm{ml}$ ), and samples were pipetted into the wells. Any HGF present was bound by immobilized antibody. After washing away any unbound substances, an enzyme-linked polyclonal antibody specific for $\mathrm{HGF}$ was added to the wells. Any unbound antibody-enzymes reagent was removed by washing with wash buffer. A substrate solution was added to the wells and color developed in proportion to the amount of HGF bound in the initial step. The color development was stopped by $2 \mathrm{~N}$ sulfuric acid and the intensity of the color was measured by microplate reader at $450 \mathrm{~nm}$. HGF concentration in each serum sample was determined using a standard curve that was created by plotting the mean absorbance for each standard against its corresponding concentration. ${ }^{(\mathbf{1 7})}$

PBMCs were separated by density gradient centrifugation over histopaque under aseptic conditions and adjusted to $1 \times 10^{6}$ cells $/ \mathrm{ml}$ in RPMI culture medium supplemented with $10 \%$ fetal calf serum, penicillin $(100 \mathrm{IU} / \mathrm{ml})$ and streptomycin $(100 \mu \mathrm{g} / \mathrm{ml})$. Cells were cultured without/with $100 \mathrm{U} / \mathrm{ml} \mathrm{IL-2} \mathrm{in} \mathrm{5 \%}$ $\mathrm{CO}_{2}$ humid atmosphere at $37^{\circ} \mathrm{C}$ for 24 hours. After culture cell suspension was centrifuged at $1800 \mathrm{rpm}$ for 10 minutes and the culture supernatant was stored at $-80^{\circ} \mathrm{C}$ until IL-10 level was measured.

\section{Determination of IL-10 level}

IL-10 was quantitatively measured in IL-2 supplemented and non-supplemented PBMCs culture supernatants by ELISA (Bender Med 
System GmbH, Vienna) according to the manufactures' procedures. AntiIL-10 monoclonal coating antibody presented onto microwells. IL-10 standard $(8.1-200 \mathrm{pg} / \mathrm{ml})$ concentration and samples were pipetted into microwells. IL-10 present in the sample was bound to antibodies adsorbed to the microwells. HRPconjugated monoclonal anti-IL-10 antibody was added and bound to IL10 captured by the first antibody. Following incubation, unbound enzyme conjugated anti-IL-10 were removed during a wash step and substrate solution reactive with HRP was added to the wells. A colored product was formed in the samples. The reaction was terminated by addition of phosphoric acid and absorbance was measured at $450 \mathrm{~nm}$. IL-10 concentration in each serum sample was determined using a standard curve that was created by plotting the mean absorbance for each standard against its corresponding concentration. ${ }^{(\mathbf{1 8})}$

Levels of IL-10 in PBMCs supernatants and HGF serum samples are presented as mean \pm SEM for each studied group.

\section{Statistical analysis}

Data of the present study were statistically analyzed using SPSS version 10 soft ware. For comparison of the means of more than two groups, one way analysis of variance
(ANOVA) was applied. A difference was considered significant at $\mathrm{P}<0.05$.

\section{RESULTS}

Urea and creatinine mean serum levels were significantly increased in CRF patients when compared with normal controls ( $p=0.00$ for both). $\mathrm{On}$ the other hand $\mathrm{Hb}$ mean blood level in CRF patients was significantly lower than that in normal controls $(\mathrm{p}=0.00)$, Table (I).

- IL-10 in Peripheral Blood Mononuclear Cells (PBMCs) of CRF patients was significantly higher than those of corresponding control groups $\left(\mathrm{p}_{4}=0.000, \mathrm{p}_{2}=\right.$ $0.000)$ respectively. Table (II).

- Supplementation of IL-2 to PBMCs of control group significantly reduced IL-10 level $\left(\mathrm{p}_{1}=0.003\right)$. The same result was obtained after IL-2 supplementation of the PBMCs of CRF patients $\left(\mathrm{p}_{3}=\right.$ 0.000), Table (II).

- HGF was significantly higher in the sera of CRF patients when compared with that of control group. $(\mathrm{p}=0.001)$, Table (III).

- On the other hand, no significant correlation was found between the levels of IL-10 released by PBMCs and HGF serum levels in $\mathrm{CRF}$ patients as well as in control group $(\mathrm{r}=0.23, \quad \mathrm{p}>0.05, \quad \mathrm{r}=0.31, \quad \mathrm{p}>0.05$; respectively). 
Table (I): Statistical analyses of the mean values of serum urea, as well as creatinine and blood hemoglobin (Hb) levels in chronic renal failure (CRF) patients and normal control (NC) groups

\begin{tabular}{|l|l|c|c|}
\hline Laboratory investigations & & CRF & NC \\
\hline Urea (mg/dL) & Range & $90-233$ & $15-30$ \\
\cline { 2 - 4 } & Mean \pm S.E.M & $167.95 \pm 8.6$ & $20.25 \pm 1.8$ \\
\cline { 2 - 4 } & $\mathbf{P}$ & $0.00^{*}$ & \\
\hline \multirow{3}{*}{ Serum creatinine (mg/dL) } & Range & $5.3-18.2$ & $0.7-1.2$ \\
\cline { 2 - 4 } & Mean \pm S.E.M & $12.32 \pm 0.72$ & $0.918 \pm 0.058$ \\
\cline { 2 - 4 } & P & $0.00^{*}$ & \\
\hline \multirow{3}{*}{ Blood Hb (g/dL) } & Range & $6.4-13$ & $11.8-16.2$ \\
\cline { 2 - 4 } & Mean \pm S.E.M & $9.28 \pm 0.41$ & $14.03 \pm 0.48$ \\
\cline { 2 - 4 } & P & $0.00^{*}$ & \\
\hline
\end{tabular}

$* \mathrm{p}$ is significant at the level $<0.05$.

Table (II): Statistical analyses of IL-10 (pg/ml) in peripheral blood mononuclear cells of chronic renal failure (CRF) patients and control group, with and without IL2 supplementations

\begin{tabular}{|c|c|c|c|c|}
\hline & Control & Control + IL-2 & CRF & CRF + IL-2 \\
\hline Range & $346.1-523.8$ & $270.3-422.1$ & $418.3-766.2$ & $346.7-415.8$ \\
\hline \pm Mean & 421.78 & 286.22 & 541.06 & 391.65 \\
\hline \pm S.EM & 15.62 & 21.04 & 32.72 & 7.40 \\
\hline$\left(p_{1}\right)$ & & $0.000 * *$ & & \\
\hline$\left(p_{2}\right)$ & & & $0.003 * *$ & \\
\hline$\left(p_{3}\right)$ & & & & $0.000 * *$ \\
\hline$\left(p_{4}\right)$ & & & & $0.000 * *$ \\
\hline
\end{tabular}

$\left(p_{1}\right)$ : Level of significance between (control) and (control + IL-2) groups.

$\left(\mathrm{p}_{2}\right)$ : Level of significance between (Control and CRF) groups.

$\left(p_{3}\right)$ : Level of significance between (CRF and CRF + IL-2) groups.

$\left(\mathrm{p}_{4}\right)$ : Level of significance between (control + IL-2) and (CRF + IL-2) groups.

** Significant at $\mathrm{p}$ level $<0.01$. 
Table (III): Statistical analyses of serum hepatocyte growth factor (pg/ml) in chronic renal failure (CRF) patients and control group

\begin{tabular}{|c|c|c|}
\hline & Control & CRF \\
\hline Range & $237.25-609.75$ & $1522.25-7747.25$ \\
\hline Mean & 517.88 & 2935.44 \\
\hline $\mathbf{\text { S.EM }}$ & 83.73 & 412.75 \\
\hline (p) & \multicolumn{2}{|c|}{$(0.001)^{* *}$} \\
\hline
\end{tabular}

** Significant at $\mathrm{p}<0.01$

\section{DISCUSSION}

The elevated levels of released IL-10 by IL-2 non-supplemented PBMCs of CRF patients than controls reflect intensive immunoinflammatory state of those patients in response to chronic inflammatory stimuli including pro-inflammatory cytokines. This finding may form a counter-regulatory mechanism to limit inflammatory process in CRF patients.

Secretion of IL-10 is suggested by Grindt et al., ${ }^{(17)}$ to be a compensatory mechanism which controls monokine induction by $\mathrm{CRF}$ patients. In their more recent study, Grindt and his associates ${ }^{(3)}$ has proven the protective role of IL-10 against systemic inflammation in CRF suggesting that IL-10 "high-producer" genotype is associated with a lower event rate and mortality than the IL-10 "low-producer" genotype.

Early studies of Matsumoto et $a .^{(\mathbf{1 2})}$ and Heidenreich et $a l^{(\mathbf{( 1 8 )}}$ suggested that elevated degree of apoptosis of $\mathrm{T}$ cell and monocytes in CRF contribute to the impaired cellular host defense seen in those patients. Now it is well established that in CRF patients, there is an increase in apoptosis of $\mathrm{Th}_{1}$ than $\mathrm{Th}_{2}$ cell subsets leading to decreased value of $\mathrm{Th}_{1} / \mathrm{Th}_{2}$ ratio. Such data together with ours explain findings of Libetta et al., ${ }^{(13)}$ who demonstrated that the constitutive release of IL-4 and IL-10 [mainly $\mathrm{Th}_{2}$ cytokines] by PBMCs of $\mathrm{CRF}$ is increased by 5-8 times in comparison with healthy control. They, also, demonstrated that the ability of PBMCs of CRF patients to secrete interferon gamma (IFN $\gamma$ was recovered after IL-4 and IL-10 neutralization.

Accordingly, the IL-2 supplementation to the PBMCs of CRF patients in the present study may partly compensate, in vitro, the loss of $\mathrm{Th}_{1}$ cells caused by apoptosis in vivo. Thus, the lower level of IL-10 in IL-2 supplemented PBMCs than that in non-supplemented PBMCs of both normal and CRF group in the present study seemed to be due to the increased proliferation of $\mathrm{Th}_{1}$ cell subset that in turn increased the production and activities of $\mathrm{Th}_{1}$ cytokines that antagonized the secretion and activities of the type which belongs to $\mathrm{Th}_{2}$ subset including IL-10. In addition, supplemented IL-2 could act directly on $\mathrm{Th}_{2}$ cells to antagonize the secretion of $\mathrm{Th}_{2}$ cytokines. ${ }^{(13)}$ 
It could, also, be suggested that decreased IL-10 level as a potent suppressor cytokine may allow different cell types to retain their normal activities including $\mathrm{T}$ lymphocytes, monocytes and natural killer (NK) cells in CRF patients which confirm the protective role of IL-2 in those patients. ${ }^{(\mathbf{1 4})}$ This protective role of IL-2 according to the current result may be relevant to the regulation of both pro-and anti-inflammatory cytokines since both are $\mathrm{Th}_{2}$ cytokines.

In this contest, Vella and his associates $^{(\mathbf{1 9})}$ demonstrated that IL-2 protects T-cells from death both in vitro and in vivo as tested in animal models. It was suggested by Wilhelm et al., ${ }^{(20)}$ that using IL-2 therapy for CRF increased T cells to normal levels, decreased gammopathy, returned renal function and gained apparently normal health status sustained for two years.

Results of the present study, also, revealed that serum HGF level was higher in CRF patients that of normal subjects. This reflects the inflammatory state of those patients as suggested by Malotino and his associates. $^{(4)}$ This finding is in agreement with results previous studies of Randers et al., (21), Rampino et al., ${ }^{(22)}$. The increased production of HGF in CRF was demonstrated to be correlated with kidney destruction and may be connected with glomerulopathy exacerbation. The higher serum HGF level in CRF is seemed to counteract inflammatory events as it was demonstrated that the beneficial effect of HGF in CRF is attributable, at least in part, to a direct anti-inflammatory action. ${ }^{(4)}$

Beside its anti-inflammatory effect, HGF is suggested to play a role in cell protection, anti apoptotic, antifibrosis and angiogenesis. Suggested mechanisms to explain these actions include, prevention of tubular cell apoptosis, blocking epithelial to mesenchymal transition and promotion of Extra Cellular Matrix degragation. Thus, the high serum HGF level in CRF may serve in ameliorating the progression of kidney disease as a potent growth-stimulating activator for a wide variety of cells. $^{(6,23)}$

Although HGF was found to be stimulated by inflammatory cytokines, ${ }^{(24)}$ and inhibited by tumour growth factor beta (TGF $\beta),{ }^{(5)}$ the role of HGF in the immune system is not well defined. However, the finding of Futamatsu et al., ${ }^{(25)}$ that HGF induces $\mathrm{Th}_{2}$ cytokines may attribute the immune response shifting to $\mathrm{Th}_{2}$ activties in CRF patients to the elevated HGF serum level in present study. Accordingly, it could be suggested that the anti-apoptotic effect of HGF in CRF patients may be directed to $\mathrm{Th}_{2}$ cell subset rather than $\mathrm{Th}_{1}$.

\section{REFERENCES}

1. Shaver MJ (2004). Chronic failure. In: Cecil Essentials of Medicine, $6^{\text {th }}$ edition. Asdreoli TE (ed), Philadelphia, W.B. Sanders company (Pub).; pp. 291300.

2. Maser B, Roth G, Brunner $M$, Lilagi T, Deicher R, Wolner E, Kovarik J, Baltz-Nitulescu G, Vychytil A, Ankersmit HJ (2003). Aberrant Tcell activation and heightened apoptotic turnover in end stage renal failure patients. 
A comparative evaluation between non-dialysis, haemodialysis and peritoneal dialysis. Biochem Biophysics Research Commun, 308: 581-5.

3. Girndt $M$, Ulrich $C$, Kaul $H$, Sester U, Sester M, Kohler $\mathbf{H}$ (2003). Uremia associated immune defect the IL-10-CRF axis. Kidney Int suppl, 84: 576-9.

4. Malotino LS, Mallamae F, Benedetto FA, Bellanuover I et al (2000). Hepotocyte growth factor predicts survival and relates to inflammation and intima media thickness in endstage renal disease. Am J kidney disease, 36: 45-52.

5. Golda E (2002). Function and regulation of production of hepatocyte growth factor (HGF). Nippon Yakurigaku Zasshi, 119: 287-309.

6. Mari T, Shimizu A, Masuda Y, Fududa Y, Yamanaka N (2003). Hypatocyte growth factor stimulating pentothal cell growth and accelerating glomerular capillary repair in experimental progressive glomerulonephrities. Nephron Exp Nephrol, 94: 44-54.

7. Bilezika B, Demirhan B, Emiroglu R, Haberal M (2003). Hepatocyte growth factor in hepatic allograft biopsies: an immuno histochemial study. Transplant Proc, 35:3022-3.

8. Guarnieri G, Grassi G, Barazzoni R, Zanetti M, BioloG (2005). The impact of inflammation on metabolic regulation in chronic kidney disease: a review. J Ren Nutr, 15:121-4.
9. Macdaugall IC (2004). Could anti-inflammatory cytokine therapy improve poor treatment outcomes in dialysis patients. Nephrol Dial Transplant, 19: V 73-78.

10. Farrar JD, Murphy KM (2001). Cytokines and type 1 immunity in: samters' immunologic disease, $6^{\text {th }}$ edition. Austen KF, Frank MM, Atkinon JP, Cautor H (ed). Philadelphia, Lippincatt willliams and (Pub). pp:104-11.

11. Alvarez-Lara MA, Carracedo J, Ramirez R, Martin- Malo A, Rodriguez $M$, Madueno JA, Aljiama P (2004). The imbalance in the ratio of $\mathrm{Th}_{1}$ and $\mathrm{Th}_{2}$ helper lymphocytes in uremia is mediated by increased apoptosis of $\mathrm{Th}_{1}$ sulset. Nephrol Dial Transplant, 19:3084-90.

12. Mastumoto $Y$, Shinzato $T$, Amano I, Takai I, Kimura Y, Martita H, Miwa M. Nakane K, Yoshikai Y, Maeda K (1995). Relationship between susceptibility to apoptosis and fast expression of peripheral blood $\mathrm{T}$ cells in uremic patients, a possible mechanism for lymphopenia in chronic renal failure. Biochem Biophys Res Common, 215: 98-105.

13. Libetta $C$, RAmpino $T$, Dalcanton A (2001). Polarization of T-helper lymphocytes toward the $\mathrm{Th}_{2}$ phenotype in uremic patients. Am J kidney Disease, 38:286-95.

14. MacNeil IA, Suda T, Moore KW, Mosmann TR, Zlotnik A (1990). IL-10. a novel growth factor for mature and immature $\mathrm{T}$ cells. Immunol, 145:4167-73. 
15. Fickenscher H, Hor S, Kupers H, Knappe A, Wittmann S, Sticht H (2002). The interleukin 10 family of cytokines. Trends Immunol, 23-:89-96.

16. Rausset F, Garcia E, Defrance t, peronne c, Vezzio N, Hsu DH, Kastelein R, Moore KW, Banchereau J (1992). Interleukin 10 is a potent growth and differentiation factor for activated human B lymphocytes. Proc Natl Acad Sci (USA), 89:1980-3.

17. Matsumori A, Miyazaki S, Takano H, Ono K, Okada M, Miyamoto $T$, Nonogi $H$, Daikoku S, Mitsudo K, Matsunaga $\mathbf{Y}$, Ohnishi $\mathbf{T}$, Daikuhara $\mathbf{Y}$, Sasayama $\mathbf{S}$ (2000). Circulating hepatocyte growth factor as a marker of thrombus formation in unstable angina pectoris. Jpn Circ J, 64: 805-7.

18. Boenisch O, Ehmko KD, Heddergo HA, Naoum C, Frei $U$ and Sthindler $R$ (2002). CReactive protein and cytokine plasma level in hemodialysis patients. J. Nephrol, 15: 547-51.

19. Girndt $\mathbf{M}$, Kohler $\mathbf{H}$, Schedhelm-Weick E, Schlaak JF, Meyer Zum Buschenfelde KH, Fleischer B (1995). Production of interleukin 6, tumor necrosis factor and interleukin 10 in vitro-correlates with the clinical immune defect in chronic hemodialysis patients. Kidney Int, 47: 559-65.

20. Heidenreich S, Schmidt $M$, Bachmann J, Harrach B (1996). Apoptosis of monocytes cultured from long term hemodiolsysis patients. Kidney Int, 49:792-9.
21. Vella AT, Daw S, Patter TA, Kappler j, Marrack P (1998). Cytokine induced survival of activated $\mathrm{T}$ cells in vitro and invivo. Proc Natl Acad Sci (USA), 95:3810-5.

22. Wilhelm $\mathbf{M}$, Wissinger $\mathbf{F}$, Kunzmann V, Muller JG, Falry JL (2001). Idiopathic $\mathrm{CD}^{+} \mathrm{T}$ cells lymphopenia evolving to monoclonal immunoglobulin and progressive renal damage responsive to IL-2 therapy. Clin Immunol, 99: 298-304.

23. Randers E, Erlandsen EJ, Kistensen JH, Marknssen S, Pedersen OL, Danislsen $H$, Jorgensen PE (2001). Serum hepatocyte growth factor levels in patients with chronic renal disease, effect of GFR and pathogenesis. Scand J Clin Lab Invest, 61:615-9.

24. Rampino I, Libetta C, Simone W, Ranghino A, Soccio G, Gregorini M, Guallini P, Tamagnone L, Dalcanton A (1998). Hemodialysis stimulates hepatolcyte growth factor release. Kidney Int, 53: 1582-8.

25. Uchiyama II, Yanager $\mathbf{K}$, Nishizaki T et al (1999). Effect of deletion variant of hepatocyte growth factor on reduced size liver transplantation in rats. Transplantation, 68: 39-44.

26. Takami Y, Kanasaki $K$, Tsubouuchi H, Ishii T, Yamanato I, Gohda E (2004). Inhibition of hepatocyte growth factor induction in human dermal fibroblast by interleukin 1 and its prevention by interferon- gamma. Biochem Biophys Res Commun, 7325:676-82. 
27. Futamatsu H, Suzuki J, Mizuno

S, Koga N, Adachi S, Kosuage H, Maegima Y, Hiraoo K,

Nakamura T, Isohe $M$ (2005).

Hepatocyte growth factor ameliorates the progression of experimental autoimmune myocarditis: a potential role for induction of $\mathrm{T}$ helper $\mathrm{Z}$ cytokines. Circ Res, 96: 823-30.

$$
\begin{aligned}
& \text { تأثير الإنترليوكين -r على إنتاج الإنترليوكين - • } 1 \text { بواسطة كرات الام البيضاء } \\
& \text { المفصولة وعلاقتها بمستوى عامل نمو خلايا الكبد فى مصل الدم الام } \\
& \text { لمرضى الفشل الكلوى المزمن }
\end{aligned}
$$

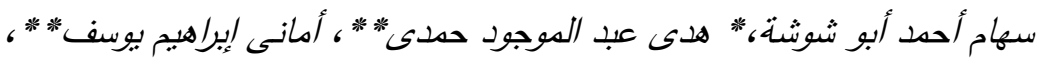

$$
\begin{aligned}
& \text { "**بsان صلاح خليل }
\end{aligned}
$$

مرض الفشل الكلوى يصاحبه ضعف فى الاستجابة المناعية - الالتهابية، تظهر كخلل فى إنتاج

محركات الخلايا الالتهابيـة وكذلك نقص في معدل الخلايـا الليمفاويـة ت المسـاعدة / / الخلايـا الليمفاويـة ت

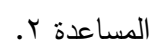

فى هذا البحث تم دراسة تأثثر الأنترلوكين - r لـ كمحفز للخلايا الليففاوية ت على إنتاج الأنترلوكين

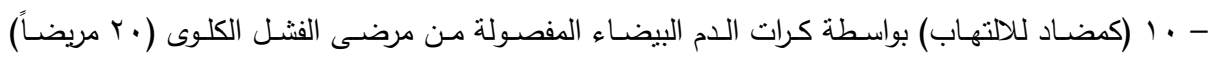

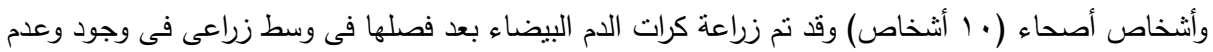

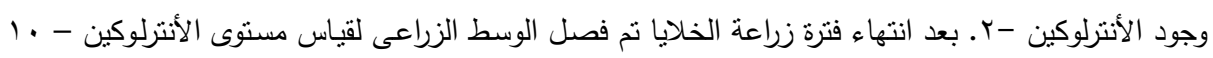

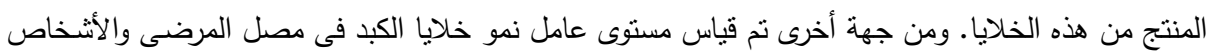
الأصحاء كليل للحالة الالتهابية لمرض الفنشل الكلوى المزمن.

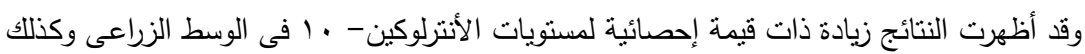

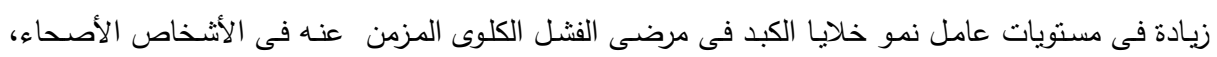

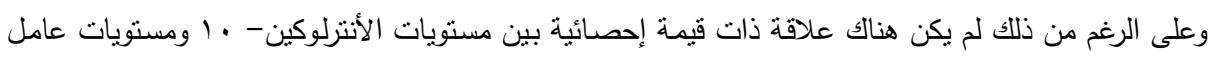

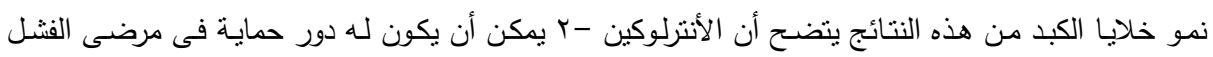

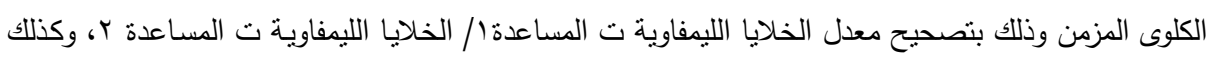

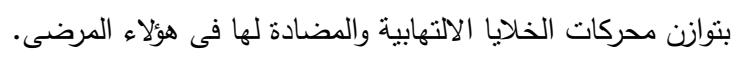

